\title{
Stomatitis sebagai Manifestasi Oral dari Anemia Defisiensi Zat Besi disertai Trombositosis
}

\section{Sarah Mersil}

\author{
Departemen Ilmu Penyakit Mulut Fakultas Kedokteran Gigi Universitas Prof. Dr. Moestopo \\ (Beragama), Jakarta, Indonesia \\ Email: sarah.m@moestopo.ac.id
}

\begin{abstract}
Studies in Indonesia stated that the main cause of nutritional anemia in adolescents is due to lack of iron intake, which is called iron deficiency anemia. One of its oral manifestations is stomatitis. Thrombocytosis is also found in iron deficiency anemia. We reported a case of a 22year-old female patient with complaints of stomatitis and further examination showed the occurrence of iron deficiency anemia and thrombocytosis. The patient was instructed to maintain good diet containing meat, vitamin C-rich vegetables and fruits, have good sleep pattern, take care of her oral health, and not to force herself to overwork. Triamcinolone acetonide in ora base $0.1 \%$ was applied on the lesion by using cotton bud after meal and before bedtime until the lesion disappeared or became painless. The patient was referred to an internist for further examination. After two weeks, the lesion had disappeared, and there was no new lesion. However, the patient had not checked to the internist, therefore, ferrous gluconate $250 \mathrm{mg}$ twice daily was given to her for 30 days. In conclusion, the patient was diagnosed as stomatitis aphthosa as an oral manifestation of iron deficiency anemia associated with secondary thrombocytosis.
\end{abstract}

Keywords: stomatitis, iron deficiency anemia, thrombocytosis

\begin{abstract}
Abstrak: Penelitian di Indonesia menyatakan bahwa penyebab utama terjadinya anemia gizi pada remaja ialah kurangnya asupan zat besi, yang disebut anemia defisiensi zat besi. Salah satu manifestasi oralnya ialah stomatitis. Kondisi trombositosis juga ditemukan pada anemia defisiensi zat besi. Kami melaporkan kasus seorang perempuan berusia 22 tahun dengan keluhan stomatitis dan hasil pemeriksaan penunjang menunjukkan anemia defisiensi zat besi dan trombositosis. Pasien diinstruksikan untuk menjaga pola makan yang baik dengan mengonsumsi daging serta buah dan sayuran mengandung vitamin $\mathrm{C}$, tidur serta istirahat yang cukup, tidak memaksakan diri secara berlebihan, serta menjaga kebersihan mulut. Diberikan obat oles yaitu triamcinolone acetonide in orabase $0,1 \%$ untuk dioles pada lesi menggunakan cotton bud sehabis makan dan sebelum tidur sampai lesi sembuh atau tidak sakit lagi. Pasien dirujuk ke spesialis penyakit dalam untuk tindak lanjut dari kondisi sistemiknya. Kontrol setelah dua minggu sariawan sudah hilang, tidak muncul sariawan baru. Pasien belum ke dokter spesialis penyakit dalam untuk memeriksa kondisi anemia yang dideritanya. Oleh karena itu diberikan ferrous gluconate $250 \mathrm{mg}$ dua kali sehari selama 30 hari. Simpulan kasus ini ialah suatu stomatitis sebagai salah satu manifestasi oral pada anemia defisiensi besi yang disertai trombositosis sekunder.
\end{abstract}

Kata kunci: stomatitis, anemia defisiensi zat besi, trombositosis

\section{PENDAHULUAN}

Anemia merupakan salah satu masalah gizi mikro yang cukup serius dengan prevalensi tertinggi dialami oleh masyarakat di Indonesia. Salah satu golongan yang rawan terhadap masalah gizi ialah remaja. Remaja sangat rawan terkena anemia dibandingkan anak dan dewasa karena remaja berada pada masa pertumbuhan dan perkembangan sehingga lebih banyak membutuhkan zat 
gizi mikro dan makro. Berdasarkan kelompok usia, penderita anemia berusia 5-14 tahun sebesar 26,4\% dan yang berusia $15-24$ tahun sebesar $18,4 \%{ }^{1}$

Jenis anemia ditentukan dari pemeriksaan darah lengkap, yaitu berdasarkan nilai mean corpuscular volume (MCV) yaitu volume sel darah merah rerata, mean corpuscular haemoglobine $(\mathrm{MCH})$ yaitu kandungan hemoglobin $(\mathrm{Hb})$ eritrosit, dan mean corpuscular haemoglobine concentration (MCHC) yaitu konsentrasi $\mathrm{Hb}$ dalam eritrosit. Pada pemeriksaan darah lengkap, sel darah merah dinyatakan normal bila MCV 80-96 fl, MCH 28-33pg, dan MCHC 33-36 g/dl. ${ }^{2,3}$ Secara morfologik, anemia dapat diklasifikasikan menurut ukuran sel dan kandungan $\mathrm{Hb}$, yaitu 1) Anemia normositik normokrom, dimana ukuran dan bentuk eritrosit normal serta mengandung hemoglobin dalam jumlah normal (MCV dan $\mathrm{MCH}$ normal atau normal dan rendah), contohnya pada kehilangan darah akut, hemolisis, penyakit kronik termasuk infeksi, gangguan endokrin, gangguan ginjal; 2) Anemia makrositik normokrom, makrositik berarti ukuran eritrosit lebih besar dari normal dan normokrom berarti konsentrasi $\mathrm{Hb}$ normal (MCV meningkat; $\mathrm{MCHC}$ normal). Hal ini diakibatkan oleh gangguan atau terhentinya sintesis asam nukleat DNA seperti yang ditentukan pada defisiensi asam folat; 3) Anemia mikrositik hipokrom, mikrositik berarti kecil, hipokrom berarti mengandung jumlah $\mathrm{Hb}$ yang kurang (MCV dan $\mathrm{MCH}$ kurang atau lebih kecil dari normal), seperti pada anemia defisiensi zat besi, keadaan sideroblastik, kehilangan darah kronis, dan pada talasemia. ${ }^{3}$

Penelitian di Indonesia menyatakan bahwa penyebab utama terjadinya anemia gizi pada remaja ialah kurangnya asupan zat besi, yang disebut anemia defisiensi zat besi. Anemia defisiensi zat besi adalah anemia yang terjadi akibat kekurangan zat besi dalam darah, artinya konsentrasi hemoglobin dalam darah berkurang karena terganggunya pembentukan sel-sel darah merah akibat kurangnya kadar zat besi dalam darah. Keadaan ini dapat menyebabkan gangguan kemampuan belajar, penurun- an kemampuan bekerja dan aktivitas fisik, serta berdampak negatif terhadap sistem pertahanan tubuh dalam melawan penyakit infeksi. Faktor-faktor penyebab anemia defisiensi zat besi ialah keadaan sosial ekonomi rendah meliputi pendidikan orang tua dan penghasilan yang rendah serta kesehatan pribadi di lingkungan yang buruk. Selain itu, penyebab anemia gizi besi dipengaruhi oleh kebutuhan tubuh yang meningkat, akibat mengidap penyakit kronis, dan kehilangan darah karena menstruasi dan infeksi parasit (cacing). ${ }^{1,3}$

Zat besi, asam folat, dan vitamin B12 sangat penting untuk proses eritropoiesis (proses pembentukan sel darah merah/ eritrosit). Sel darah merah dalam sirkulasi darah tubuh, mengangkut oksigen ke jaringan bersama hemoglobin yang didapat dari zat besi yang berada di dalamnya. Sel darah merah yang normal berbentuk bikonkaf. Jika terjadi gangguan maka sel darah merah menjadi tidak beraturan dalam bentuk dan ukuran. Hal ini menunjukkan tidak berfungsinya sel darah merah dengan baik. Pembentukan sel darah merah dalam sumsum tulang distimulasi oleh beberapa faktor nutrisi, dan yang terbanyak berasal dari vitamin B12 dan asam folat. ${ }^{2}$

Gejala umum dari anemia itu sendiri, yang sering disebut sebagai sindroma anemia yaitu merupakan kumpulan gejala dari anemia, yang akan tampak jelas jika $\mathrm{Hb}$ dibawah 7-8 g/dl dengan tanda-tanda adanya kelemahan tubuh, lesu, kelelahan kronis, pucat, pusing, palpitasi, penurunan daya konsentrasi, sulit nafas (khususnya saat latihan fisik), mata berkunang-kunang, telinga mendenging, letargi, menurunnya daya tahan tubuh, dan berkeringat dingin. ${ }^{4}$

Gejala dari anemia defisiensi zat besi: gejala ini merupakan khas pada anemia defisiensi zat besi dan tidak dijumpai pada anemia jenis lainnya, yaitu: 1) Koilonychia/spoon nail/kuku sendok dimana kuku berubah jadi rapuh, bergaris-garis vertikal dan jadi cekung sehingga mirip sendok; 2) Atrofi papila lidah. Permukaan lidah tampak licin dan mengkilap disebabkan karena hilangnya papila lidah (papila filiformis dan fungiformis); 3) Angular 
cheilitis (inflamasi sekitar sudut mulut); 4) Glositis; 5) Pica (keinginan makan yang tidak biasa); 6) Disfagia merupakan nyeri telan yang disebabkan pharyngeal web; 7) Sindroma Plummer Vinson/Paterson Kelly yang merupakan kumpulan gejala dari anemia hipokromik mikrositik, atrofi papil lidah dan disfagia; 8) Kandidiasis oral; 9) Stomatitis; 10) Erythematous mucositis; 11) Burning mouth (glossodynia); dan 12) Konjungtiva, bibir, dan mulut terlihat pucat. $^{4}$

Jumlah trombosit normal dalam tubuh manusia ialah 170.000-380.000 trombosit per mikro-liter darah. Keadaan dimana seseorang memiliki jumlah trombosit di bawah 170.000 atau kurang dari normal disebut trombositopenia sedangkan jika jumlah trombosit lebih tinggi dari 380.000 disebut trombositosis. ${ }^{5}$ Trombositosis dibagi menjadi dua yaitu primer dan sekunder. Trombositosis yang disebabkan karena defisiensi zat besi ialah trombositosis sekunder atau reaktif. ${ }^{5-7}$ Dalam 100 kasus anemia defisiensi zat besi, ditemukan tujuh kasus trombositosis. $^{5}$

Stomatitis aftosa memrupakan kasus yang sering dijumpai dalam praktek dokter gigi. Selain itu anemia masih merupakan salah satu masalah gizi mikro yang cukup serius dengan prevalensi yang tinggi di Indonesia. Oleh karena itu penulis terdorong untuk membahas suatu kasus stomatitis aftosa pada seorang pasien dengan anemia defisiensi besi dengan tujuan memberikan informasi agar dokter gigi mengetahui gejala klinis dan kelainan akibat anemia dalam mulut sehingga dapat memberikan terapi dengan tepat.

\section{LAPORAN KASUS}

Pasien perempuan seorang mahasiswi Fakultas Kedokteran Gigi program profesi tahun pertama berusia 22 tahun datang ke Klinik Penyakit Mulut Rumah Sakit Gigi dan Mulut Fakultas Kedokteran Gigi Universitas Moestopo (Beragama) dengan keluhan terdapat sariawan di bibir dalam bagian bawah kanan. Sariawan timbul 2 hari yang lalu, sariawan terasa perih dan menganggu terutama saat makan, tidak ada gejala demam. Pasien merasa timbul sariawan karena menjelang menstruasi, dan sariawan terakhir 1 bulan yang lalu. Saat ini sariawan belum diobati. Sariawan biasanya selalu timbul menjelang menstruasi dan sembuh sendiri dalam waktu seminggu. Sariawan rutin timbul semenjak menstruasi pasien teratur, sekitar 9 tahun lalu. Pasien mengaku kurang tidur serta istirahat semenjak masuk pendidikan program profesi kedokteran gigi, dan pola makan tidak teratur. Pasien memiliki riwayat anemia dan hipotensi yang diketahui sejak 9 tahun lalu, namun tidak diterapi dan kontrol rutin. Ayah dari pasien memiliki riwayat hipotensi dan nenek dari pasien juga memiliki riwayat anemia dan hipotensi.

Pada pemeriksaan klinis keadaan umum pasien didapatkan hipotensi $(90 / 60 \mathrm{mmHg})$ terlihat pucat dan lesu. Pemeriksaan ekstra oral wajah dan telapak tangan tampak pucat. Pemeriksaan intra oral tampak kebersihan mulut pasien baik dan lesi ulser tunggal, dangkal, berbentuk bulat dan berbatas tegas, berdiameter $1 \mathrm{~mm}$ berwarna putih dan tepi kemerahan pada mukosa labial regio 43 (Gambar 1). Pasien juga melakukan pemeriksaan darah lengkap dengan hasil $\mathrm{Hb}$ 9,4 $\mathrm{g} / \mathrm{dL}$ (normal 12-16 g/dL), hematocrit (Ht) $31 \%$ (normal 35-45\%), MCV 64 fL (normal 80-100), MCH 20 pg (normal 28-34 pg), dan MCHC $31 \mathrm{~g} / \mathrm{dL}$ (normal 32-36 g/dL), dimana $\mathrm{Hb}, \mathrm{Ht}, \mathrm{MCV}, \mathrm{MCHC}$ dan $\mathrm{MCH}$ turun di bawah nilai normal. Nilai trombosit pasien dari hasil pemeriksaan darah menunjukan nilai yang lebih tinggi dari normal, yaitu: $466.000 \mathrm{~mm}^{3}$ (normal 170.000$380.000 \mathrm{~mm}^{3}$ ). Berdasarkan hasil pemeriksaan tersebut kondisi sistemik pasien disimpulkan mengalami anemia mikrositik hipokromik akibat defisiensi zat besi, disertai trombositosis.

Berdasarkan anamnesis, pemeriksaan klinis dan simpulan dari pemeriksaan penunjang yang dilakukan, pasien ini didiagnosis sebagai stomatitis yang timbul sebagai manifestasi dari anemia defisiensi zat besi disertai trombositosis. Pasien diinstruksikan untuk menjaga pola makan yang baik dengan mengonsumsi daging serta buah dan sayuran mengandung vitamin 
C, tidur serta istirahat yang cukup, tidak memaksakan diri secara berlebihan, serta menjaga kebersihan mulut. Diberikan obat oles yaitu triamcinolone acetonide in ora base $0,1 \%$ untuk dioles pada lesi menggunakan cotton bud sehabis makan dan sebelum tidur sampai lesi sembuh atau tidak sakit lagi. Pasien dirujuk ke spesialis penyakit dalam untuk tindak lanjut dari kondisi sistemiknya.

Pasien datang kembali setelah dua minggu semenjak kunjungan pertama untuk kontrol. Pasien mengakui terlambat kontrol karena disibukkan dengan kegiatan kampus. Berdasarkan anamnesis, pasien sudah tidak merasa perih karena sariawan sudah hilang, tidak muncul sariawan baru. Obat yang diberikan sebelumnya telah digunakan sesuai petunjuk. Pasien telah berhenti menggunakannya saat lesinya hilang, setelah menggunakannya selama 3 hari dari saat diberikan obat. Pasien belum ke dokter spesialis penyakit dalam untuk memeriksa kondisi anemia yang dideritanya.

Pada pemeriksaan klinis, keadaan umum pasien terlihat lebih baik dari sebelumnya tetapi masih agak pucat dan lesu. Pemeriksaan intra oral tidak ditemukan kelainan (Gambar 2). Pasien juga melakukan pemeriksaan darah lengkap lagi dengan hasil $\mathrm{Hb}$ 8,5 g/dL (normal 12-16 g/dL), Ht

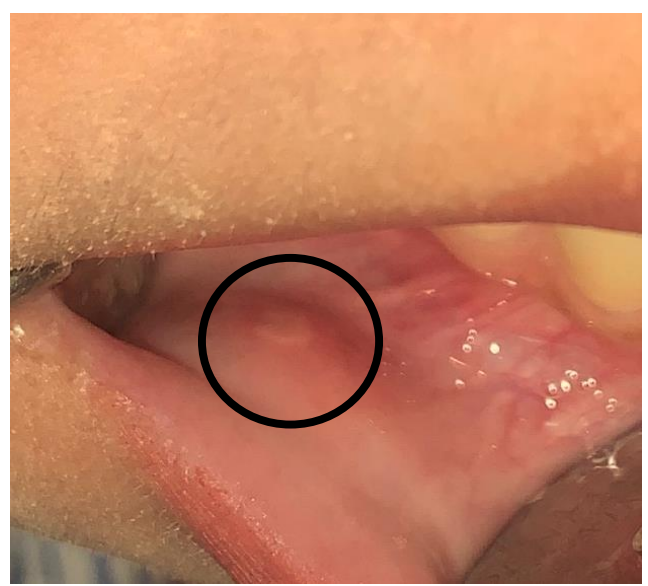

Gambar 1. Lesi ulser tunggal, dangkal, berbentuk bulat dan berbatas tegas, berdiameter $1 \mathrm{~mm}$ berwarna putih dan tepi kemerahan pada mukosa bukal regio 44
$31 \%$ (normal 35-45\%), MCV 64 fL (normal 80-100), MCH 17 pg (normal 28-34 pg), dan MCHC $27 \mathrm{~g} / \mathrm{dL}$ (normal 32-36 g/dL), dimana $\mathrm{Hb}, \mathrm{HT}, \mathrm{MCV}, \mathrm{MCHC}$, dan $\mathrm{MCH}$ masih di bawah nilai normal. Sementara itu nilai trombosit pasien juga masih di atas nilai normal dengan nilai $458.000 \mathrm{~mm}^{3}$ (normal 170.000-380.000).

Pasien terus diinstruksikan untuk tetap menjaga pola makan yang baik dengan mengonsumsi daging serta buah dan sayuran, tidur serta istirahat yang cukup, tidak memaksakan diri secara berlebihan, serta menjaga kebersihan mulut, dan mengonsumsi suplemen ferrous gluconate $250 \mathrm{mg}$ dua kali sehari selama 30 hari, serta tetap menganjurkan pasien untuk segera memeriksa kondisi sistemiknya ke dokter spesialis penyakit dalam.

\section{BAHASAN}

Pada kasus ini pasien seorang perempuan dengan anemia mikrositik hipokromik akibat defisiensi zat besi, disertai trombositosis. Anemia defisiensi zat besi merupakan hasil akhir keseimbangan negatif besi yang berlangsung lama. Bila kemudian keseimbangan besi yang negatif ini menetap maka akan menyebabkan cadangan besi terus berkurang.

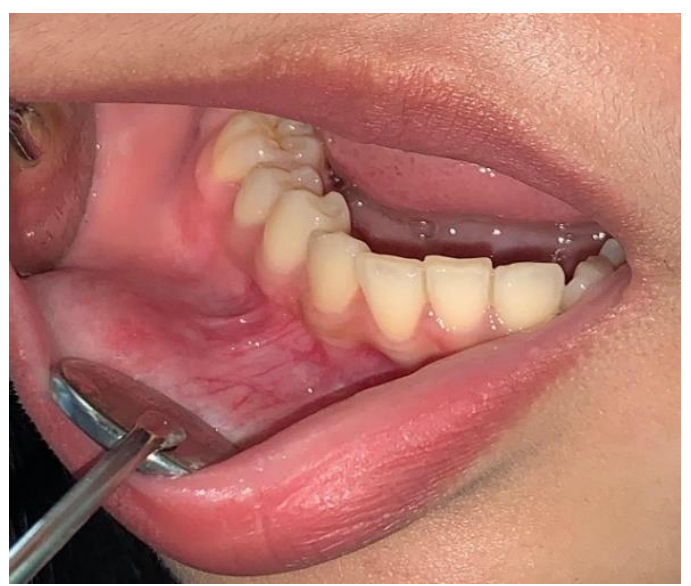

Gambar 2. Kondisi intra oral dari pasien, lesi ulser telah hilang 
Terdapat tiga tahap defisiensi besi, yaitu: 1) Tahap pertama, disebut iron depletion atau store iron deficiency, ditandai dengan berkurangnya cadangan besi atau tidak adanya adangan besi. Hemoglobin dan fungsi protein besi lainnya masih normal. Pada keadaan ini terjadi peningkatan absorpsi besi non heme. Serum feritin menurun sedangkan pemeriksaan lain untuk mengetahui adanya kekurangan besi masih normal; 2) Tahap kedua, pada tingkat ini yang dikenal dengan istilah iron deficient erythropoietin atau iron limited erythropoiesis didapatkan suplai besi yang tidak cukup untuk menunjang eritropoisis. Dari hasil pemeriksaan laboratorium diperoleh nilai besi serum menurun dan saturasi transferin menurun, sedangkan Total iron binding capacity (TIBC) meningkat dan Free Erythrocyte Porphrin (FEP) meningkat; 3) Tahap ketiga, tahap inilah yang disebut sebagai iron deficiency anemia. Keadaan ini terjadi bila besi yang menuju eritroid sumsum tulang tidak cukup, sehingga menyebabkan penurunan kadar Hb. Dari gambaran tepi darah didapatkan mikrositosis dan hipokromik yang progesif. Pada tahap ini telah terjadi perubahan epitel terutama pada anemia defisiensi zat besi yang lebih lanjut. ${ }^{3}$

Pada anemia defisiensi zat besi sering terjadi kelainan di dalam rongga mulut, antara lain berupa glossitis, glossodynia, angular cheilitis, dan recurrent aphthous stomatitis. ${ }^{2}$ Pada pasien kasus ini, kelainan yang ditemukan dalam rongga mulut adalah recurrent aphthous stomatitis. Diagnosis gejala anemia lainnya didukung dari adanya gejala klinis pasien seperti mudahlelah, lesu, dan pucat, serta timbul stomatitis minor. Anemia menyebabkan gangguan transportasi oksigen. Jaringan diberi oksigen oleh sel darah merah melalui sirkulasi darah, jadi apabila sel darah merah menurun, $\mathrm{Hb}$ menurun, maka terjadi kekurangan oksigen. Anemia yang kronis menyebabkan munculnya manifestasi klinis pada pasien seperti mudah lelah, lesu dan palpitasi. ${ }^{2}$

Patofisiologi anemia dapat menyebabkan terjadinya stomatitis adalah sebagai berikut, anemia menyebabkan aktivitas enzim-enzim pada mitokondria dalam sel menurun karena terganggunya transportasi oksigen dan nutrisi, sehingga menghambat diferensiasi dan pertumbuhan sel epitel. Akibatnya proses diferensiasi terminal selsel epitel menuju stratum korneum terhambat dan selanjutnya mukosa mulut akan menjadi lebih tipis oleh karena hilangnya keratinisasi normal, atropi, dan lebih mudah mengalami stomatitis. Anemia juga menyebabkan terjadinya kerusakan imunitas seluler, berkurangnya aktivitas bakterisidal dari leukosit polimorfonuklear, respon antibodi tidak adekuat dan abnormalitas pada jarringan epitel. Kondisi ini sering terjadi pada seseorang yang menderita defisiensi vitamin $\mathrm{B} 12$, asam folat, dan zat besi. ${ }^{2}$

Jumlah besi di dalam tubuh seorang normal berkisar antara 3-5 gram tergantung dari jenis kelamin, berat badan, dan hemoglobin. Besi dalam tubuh terdapat dalam hemoglobin sebanyak 1,5-3 gram dan sisa lainnya terdapat dalam plasma dan jaringan. Kebanyakan besi tubuh adalah dalam $\mathrm{Hb}$ dengan $1 \mathrm{ml}$ sel darah merah mengandung 1 $\mathrm{mg}$ besi $(2000 \mathrm{ml}$ darah dengan hematokrit normal mengandung sekitar $2000 \mathrm{mg}$ zat besi). Pertukaran zat besi dalam tubuh merupakan lingkaran yang tertutup. Besi yang diserap usus setiap hari kira-kira 1-2 mg, ekskresi besi melalui eksfoliasi sama dengan jumlah besi yang diserap usus yaitu 1-2 mg. Besi yang diserap oleh usus dalam bentuk transferin bersama dengan besi yang dibawa oleh makrofag sebesar $22 \mathrm{mg}$ dengan jumlah total yang dibawa tranferin yaitu $24 \mathrm{mg}$ untuk dibawa ke sumsum tulang untuk eritropoesis. Eritrosit yang terbentuk memerlukan besi sebesar $17 \mathrm{mg}$ yang merupakan eritrosit yang beredar keseluruh tubuh, sedangkan yang $7 \mathrm{mg}$ akan dikembalikan ke makrofag karena berupa eritropoesis inefektif. Secara umum, metabolisme besi ini menyeimbangkan antara absorbsi 1-2 mg/hari dan kehilangan 1-2 mg/hari. Peningkatan kebutuhan besi dapat disebabkan akibat kehilangan zat besi selama menstruasi. ${ }^{1}$ Hal ini menyebabkan pasien mengalami penurunan asupan zat besi, vitamin dan mineral yang diduga menjadi penyebab pasien menjadi anemia. 
Pada umumnya terapi yang diberikan pada pasien anemia karena kekurangan zat besi ialah tablet zat besi yang berisi ferrous sulfate, ferrous gluconate, dan ferrous fumarate secara peroral. Ferrous sulfate merupakan suplemen zat besi yang terbaik, diberikan saat perut kosong (sebelum makan). Jika hal ini memberikan efek samping seperti terjadi mual, nyeri perut, konstipasi maupun diare maka sebaiknya diberikan setelah makan atau bersamaan dengan makan atau menggantikannya dengan suplemen zat besi lain. Respon tubuh pada terapi biasanya cepat, sel darah merah akan kembali normal setelah 1 sampai 2 bulan. Oleh sebab itu, pasien diberikan suplemen yang berisi zat besi, vitamin, dan mineral 2x1 sehari yang diminum selama 2 minggu. Hal ini bukan berarti terapi dihentikan tetapi terapi harus dilanjutkan sampai 6 bulan untuk mengisi cadangan besi tubuh. ${ }^{2,4}$ Selain pemberian tablet zat besi, pasien diinstruksikan untuk pola makan yang baik dengan mengonsumsi makanmakanan kaya akan zat besi (daging, telur, ikan, hati, kacang kedelai, tahu, gandum). ${ }^{1}$ Pada pasien ini diberikan ferrous gluconate $250 \mathrm{mg}$ dua kali sehari selama 30 hari. Tidur serta istirahat yang cukup dan tidak memaksakan diri secara berlebihan serta menjaga kebersihan mulut. Pasien juga diberikan triamcinolone acetonide in ora base $0,1 \%$ sebagai obat oles, untuk dioleskan pada ulser menggunakan cotton bud. Pemberian obat ini bertujuan untuk menekan sistem kerja pertahanan tubuh (sel darah putih) yang bekerja secara berlebihan dan zat lain seperti sitokin yang dapat menimbulkan peradangan, sehingga dapat meredakan rasa sakit yang ditimbulkan oleh lesi tersebut.

Karena pada kontrol pertama setelah dilakukan pemeriksaan darah lengkap, hasilnya masih menunjukan tanda-tanda anemia defisiensi zat besi. Terapi maintenance yang diberikan ialah pemberian suplemen ferrous gluconate $250 \mathrm{mg}$. Suplemen tersebut berisi zat besi yang penting untuk metabolisme energi. ${ }^{2}$ Fungsi esensial lainnya dari zat besi antara lain, yaitu sebagai alat angkut oksigen dari paru- paru ke jaringan tubuh, sebagai alat angkut elektron di dalam sel, dan sebagai bagian terpadu berbagai reaksi enzim di dalam jaringan tubuh, dan zat besi juga diperlukan dalam pembentukan $\mathrm{Hb}{ }^{1}$

Hal lain yang menarik dari hasil pemeriksaan darah adalah ditemukannya kadar trombosit yang yang diatas nilai normal pada dua kali pemeriksaan yang dilakukan. Nilai trombosit yang di atas normal dinamakan trombositosis. Hubungan dari anemia defisiensi zat besi dengan trombositosis berkaitan dengan pembentukan sel-sel trombosit di sumsum tulang belakang. Pada laporan kasus penulis terdahulu, juga menemukan adanya trombositosis pada pasien dengan riwayat anemia defisiensi zat besi. ${ }^{8}$

Trombosit atau platelet adalah fragmen sitoplasma megakariosit yang terbentuk di sumsum tulang. Trombosit matang berukuran 2-4 $\mu \mathrm{m}$, berbentuk cakram bikonveks. Trombosit dihasilkan oleh sumsum tulang (stem sel) yang berdiferensiasi menjadi megakariosit. Megakariosit saat proses replikasi inti endomiotiknya akan memperbesar volume sitoplasma ketika jumlah inti meningkat menjadi dua kali lipat. Pada proses replikasi yang ke 8 kali, pertumbuhan sel tersebut akan berhenti. Sitoplasma akan membentuk granular dan trombosit dibebaskan dalam bentuk platelet atau kepingkeping. Tiap megakariosit dapat menghasilkan sekitar 4000 buah trombosit. Enzim pengatur utama produksi trombosit ialah trombopoetin yang dihasilkan dari hati dan ginjal. Trombosit berperan penting dalam hemopoesis dan penghentian perdarahan dari cedera pembuluh darah. Trombosit sangat penting untuk menjaga hemostasis tubuh. Abnormalitas pada vaskuler, trombosit, koagulasi atau fibrinolisis akan mengganggu hemostasis sistem vaskuler yang mengakibatkan perdarahan abnormal/ gangguan perdarahan. ${ }^{5,6}$

Defisiensi zat besi menyebabkan perubahan dalam diferensiasi megakariosit. Defisiensi zat besi menghambat proliferasi dari megakariosit, tetapi menyebabkan polyploidy (peningkatan jumlah set kromosom di dalam suatu sel) di dalam sel 
megakariosit, sehingga produksi trombosit dari satu megakariosit yang polyploidy angkanya lebih tinggi dibanding megakariosit biasa. ${ }^{6}$ Selain itu, defisiensi zat besi juga menyebabkan peningkatan pelepasan sitokin, termasuk trombopoetin yang berfungsi untuk menstimulasi pertumbuhan dan diferensiasi megakariosit dalam proses megakariopoiesis (pembentukan trombosit). Pada anemia defisiensi zat besi berkaitan dengan trombositosis yang reaktif. Thrombopoietin dan eritropoietin merupakan hormon utama yang mengatur diferensiasi dan proliferasi megakariosit. Kadar protein eritropoietin meningkat pada anemia defisiensi zat besi sehingga menjelaskan adanya trombositosis pada anemia defisiensi zat besi. $^{8}$

Trombositosis sekunder seringkali tidak menganggu dan dapat tanpa gejala dibandingkan dengan trombositosis primer. Pengobatan terhadap trombositosis sekunder ialah dengan mengatasi faktor pencetusnya ${ }^{7}$ dalam hal ini defisiensi zat besi yang dialami oleh pasien.

\section{SIMPULAN}

Kami melaporkan kasus seorang perempuan berusia 22 tahun yang menderita anemia defisiensi besi dengan stomatitis sebagai salah satu manifestasi oral disertai trombositosis sekunder sebagai akibat dari defisiensi zat besi. Diagnosis akhir ditegakkan berdasar hasil anamnesis, pemeriksaan klinis, dan didukung pemeriksaan darah lengkap.

Bahasan kasus ini memberikan informasi agar dokter gigi mengetahui gejala klinis dan kelainan akibat anemia dalam mulut sehingga dapat memberikan terapi dengan tepat.

\section{Konflik Kepentingan}

Penulis menyatakan tidak terdapat konflik kepentingan dalam laporan kasus ini.

\section{DAFTAR PUSTAKA}

1. Seflin S, Nova A, Ratag BT. Hubungan antara asupan zat besi dan protein dengan kejadian anemia pada siswi SMP Negeri 10 Manado. Pharmacon. 2015;4(4): 191-7. Doi:10.35799/pha.4.2015.10239

2. Apriasari ML, Tuti H. Stomatitis aftosa rekuren oleh karena anemia. J Dentomaxillofacial Sci. 2010;9(1):39. Doi:10.15562/jdmfs.v9i1.231

3. Fitriany J, Saputri AI. Anemia defisiensi besi. Jurnal. Kesehat Masy. 2018; 4(120200 5126):1-30.

4. Amalia A, Tjiptaningrum A. Diagnosis dan tatalaksana anemia defisiensi besi diagnosis and management of iron deficiency anemia. Majority. 2016;5: 166-9.

5. Dan K. Thrombocytosis in iron deficiency anemia. Intern Med. 2005;44(10): 10256. Doi:10.2169/internal medicine. 44.1025

6. Evstatiev R, Bukaty A, Jimenez K, Schmid W, Kulnig-Dabsch S, Surman L, Schmid $\mathrm{W}$, et al. Iron deficiency alters megakaryopoiesis and platelet phenotype independent of thrombopoietin. Am J Hematol. 2014;89(5):524-9. Doi:10.1002/ajh.23682

7. Rosdiana N, Dedy G, Lubis B, Sutjipto A, Daulay RM. 9-12 tahun yang mende-rita anemia defisiensi besi. Majalah Kedokteran Nusantara (MKN). 2008; 41(2): 112-6.

8. Mersil S, Pradono SA. Manifestasi klinis rongga mulut sebagai penanda awal penyakit iron deficiency anemia (IDA). J Ilm dan Teknol Kedokt Gigi. 2017; 13(2):1. Doi:10.32509/jitekgi.v13i2.842 